\title{
Sobre cámaras y prohibiciones. Fotografía y turismo en Los Altos de Chiapas (México)
}

\author{
On cameras and prohibitions. Photography and tourism in Los Altos de Chiapas (Mexico)
}

\author{
Eugenia Bayona Escat \\ Profesora Ayudante Doctora. Departamento de Sociología y Antropología Social. Universidad de Valencia (España) \\ m.eugenia.bayona@uv.es
}

\begin{abstract}
RESUMEN
Este artículo reflexiona sobre la prohibición de utilizar cámaras fotográficas y otros aparatos de reproducción visual en zonas indígenas de la región Altos Tzotzil Tzeltal de Chiapas, México, especialmente en los centros de mayor atracción turística con un gran número de visitantes. El estudio se centra en dos municipios indígenas: San Juan Chamula y Zinacantán, cuya población escenifica ámbitos de su cultura para el consumo turístico al mismo tiempo que interpreta a las cámaras como aparatos diabólicos y su uso como una intromisión externa. Se indaga tanto en la mercantilización de la cultura como en el empoderamiento de ciertos sectores indígenas que controlan el proceso de representación y toman nuevas posiciones sociales en la región.
\end{abstract}

\section{ABSTRAC T}

This article reflects on the prohibition of using cameras and other devices of visual reproduction in indigenous areas of the region Altos Tzotzil Tzeltal of Chiapas, Mexico, especially in the major centres of tourist attraction with a large number of visitors. The study focuses on two indigenous municipalities: San Juan Chamula and Zinacantán, where the population staged areas of their culture for tourist consumption at the same time as interpreting cameras as diabolical devices and their use as an external intrusion. It investigates both the commodification of culture and empowerment of certain indigenous groups that control the process of representation and take new social positions in the region.

PALABRAS CLAVE

turismo étnico | fotografía | escenificación | empoderamiento | Los Altos de Chiapas

KEYWO RDS

ethnic tourism | photography | staging | empowerment| Los Altos de Chiapas

\section{Introducción}

Entre la población indígena de Los Altos de Chiapas, la fotografía no ha sido una técnica utilizada en el pasado. Pocos son los indígenas que conservan fotografías de cuando eran pequeños y sus recuerdos se han construido mayoritariamente a través de una memoria oral. Las crónicas familiares construidas a través de imágenes son importantes en sociedades donde lo visual adquiere un valor de documento social que cada familia utiliza para crear su propia historia genealógica (Bourdieu 1993, Sontag 1981). Sin embargo, entre los indígenas tzotziles y tzeltales de Los Altos la fotografía ha tomado otros significados relacionados con la intromisión de una técnica externa utilizada por turistas, investigadores y foráneos que han congelado y disecado la imagen del "otro" a través de miradas fragmentadas. Recientemente, la región se ha convertido en una atracción turística a nivel nacional e internacional por el interés que tiene el turista de observar y experimentar de cerca la vida indígena. La fábrica turística ha construido y promocionado toda una gama de imágenes del mundo indígena de la región para recalcar su autenticidad y convertir a la población en un objeto de consumo atractivo para el visitante. Se promocionan imágenes por medio de guías turísticas, postales, pósters, folletos informativos, documentales, spots publicitarios e incluso series de televisión (1), cuyos protagonistas son mujeres, hombres y niños indígenas con diferentes indumentarias variedad de la composición étnica de la región. De igual forma, los turistas que acuden a esta región, ávidos por captar cualquier imagen para rememorar su estancia, reproducen con sus cámaras estas imágenes fabricadas con antelación por la mercadotecnia turística.

Los indígenas han tenido respuestas diversas ante la invasión visual que han sido objeto, y mientras algunos miran con recelo, se esconden, ocultan su cara o prohíben ser fotografiados, otros comercializan con su 
imagen y piden dinero a cambio. Algunas prohibiciones fotográficas son también creadas por las propias agencias turísticas que advierten al turista que ciertas zonas permanecen intactas para los foráneos. De esta forma consiguen también un cierto aire de misterio, prohibición y exotismo que el turista busca. Pero no se trata únicamente de una táctica de promoción turística porque así como en la capital de la región, la ciudad de San Cristóbal de las Casas, la utilización de una cámara puede ser negociada, en los parajes indígenas los artefactos de reproducción visual se han convertido en una especie de objetos malignos y diabólicos que simbolizan el rechazo que la población local tiene ante la invasión turística. En los municipios indígenas, especialmente en San Juan Chamula, la prohibición abarca cualquier aparato de reproducción, ya sea una cámara de fotografía o video, teléfonos móviles, ordenadores portátiles e incluso grabadoras que no pueden reproducir la imagen pero si el sonido externo. La utilización de algunos de estos artefactos solo está permitida con un permiso previo, concedido por las autoridades municipales y, en muchos casos, se requiere desembolsar alguna suma de dinero para compensar la trasgresión. Las únicas personas a las que se les permite utilizar la cámara son algunos pocos indígenas que se han convertido en fotógrafos o cámaras, y son ahora figuras claves para representar y documentan su propio mundo. Al contrario, en el municipio vecino de Zinacantán, el uso de la cámara es permitido en las tiendas y talleres de producción textil donde se exhibe la fabricación y venta de artesanías locales. Allí y en algunos espacios públicos, los turistas negocian precios o se les permite utilizar libremente el uso de aparatos visuales para rememorar su visita. Sin embargo, al igual que en el anterior municipio, a los turistas se les prohíbe utilizar cámaras en lugares sagrados como en el interior de las iglesias y otros recintos de culto, así como en los domicilios privados que no ha sido escenificados para el consumo turístico.

¿Por qué ahora se cuestiona el uso de cualquier aparato de reproducción de imágenes por parte de extraños al mundo indígena? La primera premisa planteada es que las prohibiciones tienen que ver con la creencia ampliamente extendida sobre el poder que tiene una cámara de robar el alma de los indígenas. Pero las diferencias que aparecen de prohibición y permisividad en el uso de la fotografía o el video entre unas comunidades y otras rompen con este discurso manejado tanto por los guías turísticos como por los propios indígenas. Tampoco nos podemos basar en el poco conocimiento que tiene la población indígena sobre estos medios visuales, ya que actualmente se promocionan fotografías, guías turísticas y documentales con autoría indígena incluso en algunas páginas de internet. Además, en los recorridos turísticos algunos guías utilizan fotografías de indígenas para enseñar aspectos que no se pueden observar en las visitas turísticas esporádicas, como algunos retratos de hombres y mujeres ataviados con trajes de fiestas o imágenes sobre celebraciones particulares. De igual forma, en las propias comunidades se venden las mismas postales de escenarios indígenas que se promociona en otros centros turísticos. Por eso, para entender estas prohibiciones, debemos partir de un contexto donde el turismo se ha convertido en la primera industria local y ha repercutido en la población receptora en muy diferentes niveles económicos y sociales. Especialmente en los municipios indígenas catalogados como de interés turístico, el fenómeno del turismo se vive cotidianamente y muchas personas se han involucrado en el negocio (vendedores, artesanas, guías, transportistas, vigilantes y cobradores entre otros). Además, ha sido la propia población indígena la que se ha apropiado de una identidad cultural "indígena" para exhibirla ante el mercado turístico y controla las rutas y los accesos a sus municipios. Es aquí, en este espacio de empoderamiento indígena, donde la práctica fotográfica se convierte en una trasgresión social en un ámbito mercantilizado en el que, sin embargo, se permite realizar otras acciones a los turistas: visitar los cementerios, pasear y comprar por los mercados locales, recorrer los campos agrícolas, asistir a fiestas y rituales, o entrar a casas particulares de producción artesanal comercializadas como auténticas.

En este artículo voy a explorar el lugar que ocupa la cámara turística en el imaginario indígena y cuáles son las causas de su prohibición o permisividad en los espacios visitados por el turista. Busco entender la fotografía como práctica articulada a discursos locales y así sugiero que la fotografía turística se ha traducido como un acto de invasión que involucra imaginarios sobre cómo interpretan los indígenas a los turistas, con estereotipos que oscilan entre un acto consumista y típicamente occidental, como una invasión y falta de respeto a la comunidad y a sus creencias, o como una presencia que puede llegar a contaminar la pureza de las tradiciones indígenas. Sugiero, además, que tras estas prohibiciones hay un discurso político de las clases en el poder que utilizan la pureza y la tradición cultural como mecanismos para imponer sus intereses políticos y mercantiles. Pretendo demostrar cómo el ámbito del turismo ha servido para conquistar una agencia indígena y cómo las nuevas élites utilizan el escenario turístico para representarse ante los otros extranjeros en unos escenarios traseros que se han transformado en frontales por ser adecuados para la presentación de esa "otredad" que busca el imaginario turístico (Boissevain 2005, MacCannell 2003). Así, propongo indagar en estos escenarios frontales, que se perciben como traseros y auténticos, donde 
aparecen de manera más condensada ciertos elementos de representación que sirven a la vez para fortalecer una ideología sobre la pureza y tradición de la cultura indígena. Desde esta perspectiva, quiero comprender esta relación existente entre turismo y empoderamiento indígena a través del control que ejercen algunos grupos para decidir qué elementos culturales pueden ser escenificados o prohibidos para preservarlos de la mirada turística. Para ello, propongo la comparación de los dos municipios indígenas más visitados de la región: San Juan Chamula y Zinacantán, ya que entre ambos municipios se establecen diferencias sustanciales en torno a la prohibición y permisividad del uso de las cámaras de extranjeros, al mismo tiempo que cada uno de ellos ha escogido diferentes escenarios para exhibirse ante los turistas y difieren sustancialmente los discursos y prácticas que desarrollan ante los visitantes.

Dado el interés de este trabajo por la perspectiva del actor social, anclado en una situación y ámbito específico como el turismo, la metodología de investigación utilizada ha sido la realización de trabajo de campo etnográfico con el objetivo de recoger y registrar información empírica de fuentes primarias (2). Se privilegió el registro, análisis e interpretación de los discursos que manejan los distintos agentes sociales que participan en el contexto turístico. Por tal motivo se aplicaron las técnicas de investigación propias de la etnografía: principalmente la observación participante (recorridos de tours por todos los centros de visita) y la entrevista cualitativa a informantes claves en cada municipio (anfitriones de cada municipio con contacto con turistas) combinado con otras entrevistas informales a vendedores y guías turísticos. La cámara fotográfica se ha utilizado aquí como un medio para pensar en las nuevas posiciones sociales que toman los actores locales más allá de las dicotomías jerárquicas y desiguales que han imperado en las representaciones visuales y percepciones propias del "otro". Con ello me refiero a cómo la cámara ha representado a esos "otros" bajo parámetros europeos y los ha demarcado en los modelos de representación propios de Occidente; en sus primeras épocas con ambiciones colonialistas y bajo una mirada construida al servicio de la ciencia y del control político (Banks y Morphy 1997, Edwards 1992, Pratt 1992) y en la actualidad, a través de un discurso apropiado por la industria turística bajo una mirada esencialista y atemporal para su consumo global (Urry 1990, Urry y Crawshaw 1995). Sin embargo, ahora asistimos a otra realidad donde esos "otros" se piensan y representan en un mundo plagado de imágenes distorsionadas sobre sí mismos, cuestionan los antiguos modelos de representación y prohíben o permiten el uso de una cámara externa para sus propios beneficios.

\section{Recorridos turísticos en Los Altos}

La región Altos Tzotzil-Tzeltal ha experimentado en los últimos años un crecimiento importante del sector turístico y se ha convertido en lugar de paso obligado de los tours que promocionan el sur de México. Se trata de una de las regiones más densamente pobladas del estado de Chiapas, con una mayoría de población indígena tzotzil o tzeltal que vive en el ámbito rural bordeando la ciudad cabecera de San Cristóbal de las Casas (3). Desde la década de 2000, la industria turística se ha convertido en el principal recurso económico de la zona, y cada día llegan más visitantes tanto nacionales como internacionales que acuden principalmente para conocer los diversos pueblos indígenas que alberga la zona. Desde organismos estatales e inversiones privadas se ha promocionado el sur de México como un lugar paradisíaco para que el turista contemple el exotismo de las tradiciones indígenas y se han creado diversos escenarios étnicos que se acoplan a la mirada e imaginarios de los turistas. La promoción del turismo étnico y cultural en la zona se ha basado principalmente en dos polos de atracción: la ciudad de San Cristóbal de las Casas como antiguo centro colonial, con numerosos monumentos que recuerdan su pasado, y la visita guiada a los municipios indígenas de San Juan Chamula y Zinacantán donde sus habitantes son presentados ante el mercado turístico como antiguos descendientes mayas que preservan su pasado en costumbres como la agricultura, la alimentación, la vestimenta, las artesanías, las fiestas y algunos rituales.

A pesar de todo, se trata de una las regiones más pobres y marginadas de Chiapas que contrasta abiertamente con estas visiones escenificadas que construye la industria turística (4). La población indígena supera en número a la mestiza, y hasta bien entrada la década de 1950 se han mantenido relaciones de dominio coloniales con el control y poder de los ladinos (como se conoce a los mestizos en Chiapas y Guatemala) aposentados en la capital de San Cristóbal, sobre una masa indígena campesina y cada día más empobrecida. Actualmente, una gran parte de la población indígena es pobre y tiene serias dificultades para la sobrevivencia. Mantiene su labor en el campo y se dedica a la producción y comercialización de 
productos agrícolas y artesanales, como textiles y barro, que derivan al mercado centralizado de San Cristóbal. Los desplazamientos por la revuelta zapatista de 1994 y las expulsiones comunitarias de indígenas que se convierten al protestantismo u otras religiones, han provocado la migración masiva a la ciudad de migrantes indígenas que intentan sobrevivir en la ciudad (5). Los beneficios que ha comportado el turismo han sido desiguales para los participantes locales: algunos residentes, especialmente los mestizos que residen en la capital, se han convertido en empresarios y se han sumado a las iniciativas de extranjeros que han efectuado grandes inversiones en servicios turísticos. Otros han consolidado negocios de venta de artesanías, al contrario de una gran mayoría de mujeres y hombres indígenas que se ha incorporado al trabajo asalariado en el sector servicios y a un mercado ambulante de souvenirs destinados exclusivamente al consumo turístico. Aun así, un sector de indígenas locales ha conseguido capturar algunos espacios turísticos importantes; algunos se han convertido en empresarios o comerciantes a gran escala de artesanías $\mathrm{o}$ frutas y verduras con redes que extienden entre indígenas urbanos y rurales, otros en funcionarios del gobierno o en cooperantes de organismos internacionales, en artistas y artesanos o en agentes turísticos y representantes oficiales de su cultura de cara al visitante externo, lo que les ha permitido negociar posiciones sociales y acrecentar su poder urbano y local.

La región se convirtió en un centro de interés internacional a raíz del levantamiento zapatista de 1994, como lugar simbólico de lucha y levantamiento revolucionario indígena, y como base central para la actuación de numerosas ONG, en defensa de los derechos de los pueblos indígenas. Pero el impulso turístico se fortalece a partir de la década de 2000, cuando las inversiones estatales y privadas vuelven a tomar las riendas en la ciudad de San Cristóbal de las Casas tras una etapa incierta ante la revolución zapatista, y se establece una infraestructura necesaria para acoger a todo tipo de turistas. Desde los organismos estatales se emprende un proceso de rehabilitación del patrimonial histórico de monumentos, casas coloniales, iglesias y plazas principales, al mismo tiempo que aparecen agencias de viajes y servicios asociados, como hoteles, restaurantes y tiendas, que promocionan la ciudad como un atrayente destino turístico (Sánchez Flores 1995). Actualmente, la región se halla enclavada en el circuito turístico del Mundo Maya, que incluye las ruinas de Palenque, el Caribe y la Península de Yucatán (6), y desde San Cristóbal salen numerosos tours que se dirigen a las atracciones turísticas de todo el estado de Chiapas; hacia el norte a las ruinas arqueológicas de Palenque, Yaxchilán, Bonampak y Toniná, o las rutas naturales del Cañón del Sumidero, Grutas Rancho Nuevo, Lagos de Montebello, Cascadas de Agua Azul o Misolhá. Los viajes organizados a pueblos indígenas incluyen en Los Altos a San Juan Chamula, Zinacantán y Amatenango del Valle, y en la Selva Lacandona a Lacanjá. También se promociona el paseo y estancia por las ciudades coloniales como Chiapas de Corzo y la misma San Cristóbal de las Casas que ha promocionado su pasado glorioso para consumo cultural y ha sido declarada Zona de Monumentos Históricos y catalogado como Pueblo Mágico (7).

El turista que arriba a Los Altos se decanta cada vez más por observar a la población indígena y ha aparecido en escena el turista étnico, interesado en la vida y cultura de la población autóctona que vive alrededor de la ciudad. El turista étnico, interesado en encontrar la "autenticidad" en grupos indígenas, nativos, aborígenes y/o étnicos, busca lugares supuestamente menos comercializados y al margen del turismo de masas estandarizado para experimentar con el contacto con el "otro" y con sus costumbres "típicas" y "exóticas" (Santana 2003a y 2003b, Smith 1992). En Los Altos se promocionan las tradicionales comunidades indígenas como esos "otros exóticos" (Van den Berghe 1994 y 1995) que pueden ofrecer "auténticas experiencias" a los turistas (MacCannell 2003, Wang 1999). No obstante, muchos de los turistas nacionales y extranjeros que llegan en autobuses desde la capital y otros estados mexicanos, contratan agencias para planificar las rutas, y los guías y los libros les explican lo que tienen que observar. Las imágenes publicitarias enseñan esos iconos visuales globales, como afirma Urry (1990), que proyectan los imaginarios y estereotipos occidentales sobre ese "otro", y construyen formas reglamentadas de ver de los turistas para que sean identificables. Además, el contacto con los grupos autóctonos se halla mediado por intereses turísticos y por los propios indígenas, que se han convertido en los representantes oficiales de su cultura y promocionan una serie de escenarios frontales, como señala MacCannell (2003) (8), que esconden entre bastidores la vida local de los que se convierten en anfitriones. Así, se ha ido consolidando un tipo de turista que observa y experimenta con esos "otros exóticos" que se promocionan a sí mismos y contribuyen a la recreación del imaginario indígena para su consumo turístico.

La población indígena de Los Altos exhibe y mercantiliza algunos aspectos de su cultura para atraer a los turistas (Greenwood 1992). El mismo discurso potenciado por la industria turística sobre comunidades tradicionales y exóticas ha sido apropiado por las comunidades locales para incentivar un mercado interno 
local y fortalecer su identidad y poder local. Como afirma Cohen (1988), el turismo ha servido a los locales para rescatar o reinventar partes de su cultura, aunque para ello han tenido que poner en marcha un esencialismo estratégico (Spivak 1988) (9) para conseguir cierto protagonismo en el mundo global que valora al "otro" bajo coordenadas mercantiles. Así, mientras en algunos municipios indígenas, como el caso específico de Tenejapa, se ha prohibido la entrada a los viajes organizados promovidos por las agencias, en otros se han multiplicado en los últimos años. El acceso a los dos municipios indígenas más cercanos a la ciudad, San Juan Chamula y Zinacantán, se organizan por agencias externas que contratan en su mayoría a guías no indígenas. Sin embargo, es necesario pedir permisos para entrar a las cabeceras, pagar por la entrada de los autobuses y hacer acuerdos con las autoridades para visitar los espacios permitidos. La visita de ambas comunidades se efectúa en un mismo día y en cada una de ellas se muestran diferentes aspectos de la cultura "tradicional" indígena: en San Juan Chamula se oferta un recorrido por algunos espacios sagrados e incluye la observación de "auténticos rituales indígenas", mientras en Zinacantán el escenario turístico se construye mediante la exhibición de la producción y venta de textiles, promocionadas por los guías como "auténticas artesanías mayas". Las autoridades de cada municipio han ideado las rutas más adecuadas y los espacios que pueden ser vistos, al mismo tiempo que exigen una cuota de entrada para acceder a la cabecera municipal o a los recintos sagrados. Los visitantes son guiados por los principales centros de atracción turística, recorren las plazas centrales en el que deambulan mujeres y niños con mercancía para la venta, visitan los mercados de artesanías con productos turísticos locales o procedentes de otras regiones o países, y entran a los recintos sagrados como iglesias y capillas abiertas al público. El crecimiento del turismo ha provocado reacciones muy diferentes en una y otra localidad en relación a la utilización de aparatos de reproducción visual; mientras en San Juan Chamula se prohíbe el uso de las cámaras en prácticamente todos los lugares públicos y se acentúa la prescripción en el interior de la iglesia bajo amenazas de multas y encarcelamiento, en Zinacantán, al contrario, se permite fotografiar a mujeres y niños en lugares públicos previo pago monetario y está totalmente permitido en las tiendas de producción y venta de textiles que se visitan como parte del tour turístico.

La promoción de estos espacios turísticos ha requerido complejas negociaciones entre los guías y las autoridades locales indígenas quienes documentan a los primeros sobre la información necesaria para la presentación turística. Los encuentros con los indígenas están mediados por los discursos de los guías que prometen al visitante una experiencia única, una especie de viaje al pasado para acercarse a los vestigios de una población indígena, india o maya, según las diferentes versiones de las agencias, que conserva su propia lengua, viste con trajes tradicionales y celebra rituales exóticos. De ellos dependen las visiones que los turistas se llevarán de este entorno vendido como exótico y de los posibles contactos e interacciones que van a tener con la población local. Los guías te cuentan que las diferencias entre una y otra localidad se establecen por sus rasgos culturales, como el traje que portan mujeres y hombres en cada localidad y la creencia de santos y diversas ceremonias religiosas, algunas de las cuales pueden ser observadas en vivo por el turista. Además, los guías constantemente advierten de las prohibiciones y contribuye a recrear el imaginario de una población indígena que parece ajena a los adelantos tecnológicos (10):

"Por favor no vayan a sacar cámara, no vayan a sacar celular, nada, porque mucha gente nos están vigilando, nos están cuidando. Un favor, que guarden bien su cámara, los celulares porque los celulares son de alta tecnología. Mucha gente nos está vigilando, nos está cuidando. Ahora si que el que toma fotos ya es bajo su responsabilidad".

O advierten sobre los males que les acechan como indígenas y cómo en determinados espacios sagrados las prohibiciones se agudizan:

"Tienen que ser muy cuidadoso con las fotos. No todos aceptan que se les tome la fotografía, porque piensan que se les roba el alma. Siempre hay que preguntar antes, pedir permiso. En todas las comunidades está prohibido (...) En el cementerio se puede tomar fotos desde lejos, pero en la iglesia nunca".

'Los 'usos y costumbres' dicen que está prohibido tomar fotos adentro de la iglesia, los pueden meter a la cárcel por tomar una foto, y no hay nada que yo pueda hacer. No se toman fotos adentro de la iglesia. Si vemos autoridades religiosas o procesiones, no les vayan a tomar fotos por favor. Traen la funda de su cámara o una mochila y antes de entrar a la iglesia pongan su cámara en la mochila o en su funda. No la vayan a traer en la mano o en el cuello adentro de la iglesia, afuera sí, no hay problemas, pero adentro guárdenla por favor". 
Las prohibiciones tajantes no han sido creadas por las agencias sino por una imposición de los anfitriones que permiten poco contacto y pautado exclusivamente para exhibir una cultura que parezca diferente para incrementar su valor comercial. Durante las visitas que realizan conjuntamente con los guías, los turistas tienen poco contacto con los locales, las visitas son esporádicas y de pocas horas, pero, sin embargo, alteran completamente la dinámica de sus habitantes. El turismo en cada uno de los dos municipios se ha convertido en un fenómeno cotidiano y muchos de sus pobladores sobreviven o intentan sobrevivir del mismo. Se promueve la exhibición de trajes, se promocionan productos locales, se exhiben técnicas artesanales y centros de culto, y en definitiva, se escenifican ámbitos culturales en escenarios frontales que se acoplan a los imaginarios turísticos. Cuando llegan los autobuses turísticos la dinámica de cada pueblo cambia: algunas casas se cierran las ventanas y puertas mientras otras permiten ser visitadas, los niños y mujeres salen a recibir a los turistas con mercancía la venta, mientras se visten y se trajean con su indumentaria tradicional para darse a conocer y presentarse ante los turistas. La estrategia comercial de los indígenas consiste en presentarse a sí mismos como diferentes ante los turistas y no parecen cuestionar ese simulacro que esconde la realidad marginal en la que vive la mayoría de la población campesina. Son el escenario adecuado para que los guías rellenen sus historias sobre la pureza de una cultura indígena que no permite incluso ser fotografiada, lo que incentiva el misterio de una tradición arraigada en un pasado mítico. Sin embargo, la realidad entre bastidores es muy diferente; las ganancias del negocio del turismo son desiguales y el control de la actividad turística se reparte entre los propietarios mestizos en la ciudad que poseen hoteles y restaurantes, las agencias turísticas, los líderes indígenas y algunos comerciantes que son los que explotan los estereotipos étnicos para beneficio propio. Aunque todos ellos contribuyen a crear un ambiente adecuado para que el turista vuelva a sus hogares y memoriza sus experiencias, para algunos estas representaciones se han convertido en un medio de vida incierto, mientras que otros lo utilizan como una estrategia de presentación que les permite negociar posiciones sociales y acaparar un mayor poder local.

\section{La ruta sagrada en San Juan Chamula}

La cabecera municipal de San Juan Chamula (11) se ha convertido en un lugar de visita obligada para los tours turísticos que hacen un recorrido por las principales calles, visitan el cementerio y la iglesia principal de San Juan Bautista. Dicha cabecera funciona principalmente como centro político, ceremonial y administrativo para sus habitantes y es un importante centro de distribución y venta de productos agrícolas y otros enseres. Desde la última década se ha convertido también en el lugar de residencia de las clases políticas y religiosas más adineradas, que han construido grandes casas y han abierto nuevos negocios, como tiendas de artesanía y alimentos, e incluso algunas cafeterías que ofrecen bebidas a los turistas. Bordeando la cabecera se encuentran pequeñas localidades en parajes que no son visitados por turistas y donde vive una mayoría de población campesina que subsiste de la producción agrícola y de la escasa comercialización de excedentes en el mercado interno y mayoritariamente centralizado en San Cristóbal de las Casas (12). Algunas mujeres indígenas producen y/o venden artesanías para el mercado local con beneficios escasos por la competencia existente ante la demanda turística. Además, desde la década de 1990, se ha producido una concentración de tierras para el cultivo en manos de propietarios indígenas enriquecidos que inauguran monocultivos y agudizan las diferencias entre una minoría indígena rica y una gran mayoría pobre. La migración temporal o definitiva, tanto nacional como internacional, ya se ha convertido en la mejor opción para los jóvenes, junto al trabajo asalariado, cada vez más escaso, en ciudades como San Cristóbal que demanda mano de obra para los servicios turísticos (Pineda 1995, Rus 1995 y 2011 , Viqueira 1995 y 1999).

En el municipio se practica una forma de autogobierno, o la costumbre, bajo el poder de las autoridades político/religiosas que apelan a una serie de normas sociales que deben ser acatadas para el buen funcionamiento comunal. El gobierno de las élites, formado por unas cuantas familias y parientes allegados, impone un discurso de conservación de la tradición indígena de creencias, saberes y normas, al mismo tiempo que mantiene el control a través de cargos políticos y religiosos que se alternan y entrelazan unos con otros (13). El sistema político municipal y autónomo se basa en el ascenso jerárquico a cargos como Presidente Municipal, Regidores, Jueces, Escribanos o Policías, junto a la participación en un complejo y jerárquico Sistema de Cargos, en el que las autoridades políticas designan a una serie de oficios masculinos religiosos, las mayordomías, cuyas obligaciones son cuidar y limpiar la iglesia, celebrar fiestas para los santos y rezar para la comunidad (14). La élite corporativa consolida su poder mediante el 
fortalecimiento de lazos familiares y de una red de amistades, compadrazgo, deudas, favores y amenazas como mecanismos de coacción social que le permite ir subiendo en la escala, conquistar ámbitos económicos estratégicos y controlar negocios como el transporte regional y los medios de producción y distribución de productos (agrícolas, bebidas y utensilios ceremoniales) (Pineda 1995, Rus 1995 y 2011 , Viqueira 1995 y 1999). Actualmente, la gran mayoría de los negocios relacionados con el turismo son manejados por dichas élites, que controlan el transporte de la ciudad hacia los municipios, el pago de la entrada a las cabeceras municipales y/o recintos sagrados, e incluso el control que poseen de algunas cadenas comerciales de artesanías mercantilizadas como indígenas.

Las élites indígenas se encargan de promover la cultura indígena ante los turistas y exhiben, de manera particular, las prácticas rituales como uno de los aspectos más interesantes de su tradición; los rituales que se celebran en la iglesia cabecera de San Juan Bautista donde se practican una serie de ceremonias en las que caben múltiples actividades: curaciones, plegarias, rezos y peticiones; y se utilizan una serie de objetos como animales, velas, incienso y refrescos que los convierten en materia perfecta para la explotación turística. La iglesia se halla custodiada por las autoridades municipales, que exigen el pago monetario para entrar al recinto. No se permite hablar ni utilizar cámaras en su interior, ni tampoco molestar a los creyentes que parecen ajenos a la muchedumbre que los visita diariamente. De cara al turismo, la iglesia se promociona como "un ritual mezcla del catolicismo y creencias indígenas con antecedentes prehispánicos en la que se cura el alma enferma del indígena". Los guías hablan de un sincretismo religioso por la combinación de prácticas y creencias mayas y católicas que sirven para sanar los males del alma, más que del cuerpo, mediante "una tradición milenaria en estrecho contacto con la naturaleza". Por su parte, los mandatarios indígenas presentan el centro ceremonial como "un ombligo del mundo", a través de una vida netamente "ritual y ceremonial". Estamos humilde y totalmente conectados con la "Madre Tierra" y "el cosmos". Además, se presentan ante los turistas con un discurso tradicionalista: "Mediante estrechos vínculos, hemos podido conservar ciertas tradiciones y costumbres tan antiguas que algunas provienen de los Mayas y por ello estamos sumamente orgullosos de nuestra cultura" (15).

Los chamulas acuden a la iglesia de San Juan Bautista para rezar, pedir sus súplicas y bendiciones a los santos, o para curar sus males con la ayuda del ilol o pulsador, que por medio de rezos y limpias pronostica las dolencias y cura a los enfermos (16). Toma el pulso del enfermo y determina la naturaleza de la enfermedad: el espanto, el mal echado, la pérdida del alma, o males por trasgredir norma sociales y morales. Las creencias de los tzotziles en torno a la salud y enfermedad están relacionadas con valores naturales sobre la concepción que poseen del cuerpo y el alma, unido a una serie de valores sociales asociados al respeto a la costumbre y la tradición comunal. La concepción de la persona se compone de un cuerpo, el bak'etal, y varias almas entre las que se encuentran el ch'ulel y animales compañeros y criaturas extrañas, denominados chanuletik, lab o wayjel. El ch'ulel es el alma que cada persona posee en su interior y puede desprenderse del cuerpo debido a una caída o susto, por lo que debe ser llamado por el i'lol para que la persona recupere su salud. Los niños son los más propensos a padecer el desprendimiento porque todavía tiene un alma débil. Por su parte, el lab o wayjel es un animal que viaja durante el sueño y puede extraviarse o no encontrar el camino de regreso y requiere también la ayuda del ilol para volver a encontrar el cuerpo que habita (Guiteras 1965, Pitarch 1996). La enfermedad puede tener algunas causas naturales, estar relacionada con la debilidad propia de cada cuerpo, el frío o calor excesivo, o puede estar causada por el abandono de alguna de las almas que cada persona posee en su interior que se extravía o no encuentra su camino de regreso. A la vez, existen causas sociales que provocan males e incluso llevan a la muerte y requieren tanto la intervención del ilol como del rezador de los cerros que con sus oraciones protege a la comunidad de todos estos males sociales. Algunas enfermedades tienen que ver con el enojo y los malos deseos, o la envidia de personas que dirigen sus malas energías hacia otras y provocan el "mal echado", mientras otras provienen de las trasgresiones sociales efectuadas por las personas que incumplen normas de conducta y no tienen respeto hacia sus tradiciones (Freyermunt 1993). El incumplimiento de las normas provoca desequilibrio moral, y por tanto corporal. Ello influye en el cuerpo individual de una persona, pero también social porque al no cumplir con tu familia y vecinos, al no respetar a tus mayores o no atender tus obligaciones religiosas, pones en riesgo el buen funcionamiento de toda la comunidad

Todas estas enfermedades sociales, al igual que las anteriores, deben buscar su remedio en las curaciones efectivas que realizan los expertos en cada materia. El i'ol es el encargado de curar los males del cuerpo y del alma mediante sesiones terapéuticas en las que se utilizan una serie de objetos sagrados como flores, velas, incienso, gallinas, huevos, bebidas alcohólicas como el ceremonial posh (17) y otros refrescos que tienen propiedades gaseosas para limpiar el cuerpo (Coca-cola, mayoritariamente, pero también otras 
bebidas con gas como Pepsi, Fanta y Sprite). Las velas se utilizan de diferentes tamaños y colores según el pronóstico y la gravedad de la enfermedad, y se tienen que quemar por completo porque representan, al igual que las flores, el alimento de Dios (o dioses) y los santos (18). La gallina o el pollo (o en su caso los huevos), se pasan por el cuerpo del enfermo para hacer las limpias y luego se sacrifican porque han absorbido el mal y ya no son comestibles. Igualmente, el posh y los refrescos se soplan, beben o pasan por el cuerpo para quitar enfermedades y fortalecer a la persona. Algunos de estos objetos sagrados, como las velas, las flores o el incienso de los copales, son también utilizados cuando los fieles rezan en la iglesia y coloca estos objetos sagrados para pedir las súplicas y hacer ofrendas ante los santos.

El turista acude a este escenario trasero que se ha convertido en un escenario frontal mercantilizado para su exhibición turística (Greenwood 1992, MacCanell 2003) y se le permite observar las curaciones efectuadas en el interior del recinto, así como las peticiones y ofrendas que los creyentes efectúan ante los numerosos santos. El turista observa pero no participa, porque los chamulas no permiten interrupciones en sus oraciones y ceremonias de curación y permiten la entrada pero no la intromisión. La presencia del turista comporta reacciones locales y se han creado diferentes discursos y actitudes sobre el turista, y mientras la gran mayoría desvía la mirada de los visitantes y hace ver que no existen, otros afirman que las cámaras pueden traer consecuencias graves a su cuerpo y alma (19): "Las personas se enfadan si las retratas. Ya no es igual que antes que miraban asombrados con una cámara. Ahora no quieren porque se sienten ofendidos. Piensan que tomar una foto puede hacerles algún mal". Son los males que ejercen los turistas en un espacio sagrado donde el curandero tiene la tarea de llamar a las almas perdidas para que el cuerpo recupere su energía vital. Por eso, las creencias en torno a que una cámara puede robar el alma se agudizan: "Tu llegas a pedir a los santos, a ser curado por el ilol, tu alma vuela y puede ser atrapada". Porque sin alma, los indígenas se quedan sin memoria, sin sentimientos ni emociones, sin sueños o lenguaje, y porque allí residen las características de cada persona y su ausencia prolongada puede provocar que te quedes sin energía y morir poco a poco (Pitarch 1996).

Hay además un discurso institucional sobre los efectos que provoca una cámara, y ante la invasión turística ha aparecido una nueva enfermedad provocada por los aparatos de reproducción visual que pueden hacer mella en el cuerpo y debilitar la salud de los indígenas, como me comentó un informante: "Ahora los curanderos hablan de los males, de las enfermedades que provocan a las personas si las fotografías. Si una persona está enferma, el curandero comenta que fue por una fotografía y ellos piensan que es una forma de hechizo y que los maltratas". Los curanderos han clasificado una nueva enfermedad provocada por agentes externos, los turistas, que se han convertido en una especie de agentes del mal que captan almas a través de sus cámaras y enferman cuerpos. Por eso, estos discursos institucionales son tan eficientes, porque afectan a un cuerpo que refleja con la salud su condición comunitaria y social. Si se le permite a un extranjero tomar fotos se comete una trasgresión que repercute a nivel individual y social, y la norma queda establecida por las autoridades que imponen fuertes multas para quién se atreva a traspasar la prohibición. Así, el cuerpo social se convierte en político, como alude Scheper-Hughes (1997), al ser reflejo del control social que ejercen los representantes del orden político y religioso que legitiman normas y obligan a seguir las tradiciones comunales. La enfermedad pone en cuestión el buen o mal comportamiento que una persona tiene hacia los que le rodean, y de esta forma trasgredir la costumbre se convierte en un mal que puede provocar desequilibrio interno, e incluso la muerte.

Pero además, más allá de lo que una cámara puede provocar en el cuerpo de cada individuo, la prohibición refleja que la tradición reinventada y mercantilizada ante los turistas debe ser protegida ante los ojos extraños. La prohibición de utilizar las cámaras impuesta por los mandatarios no puede ser rebasada y se extiende, además, fuera del ámbito de la iglesia: en las calles que recorren los turistas, en los mercados o en el cementerio; y si se permite, solo se pueden tomar panorámicas generales sin gente protagonista. Aquí, en los espacios públicos, los imaginarios que corren sobre las prohibiciones no son unitarios. Para algunos anfitriones las prohibiciones tienen que ver con el uso desproporcionado que se ha hecho de su imagen sin su consentimiento: "No permiten ya vender su cultura porque saben que comercias con la imagen de ellos". Otros te hablan de alto precio que pagan los turistas si transgreden la norma: "Cuando tomas fotos pueden meterte en la cárcel, no les gusta porque no compras nada", o más concretamente, la falta de respeto hacia su cultura: "No dejan tomar fotos porque le tienen respeto a sus dioses, por eso mismo no permiten. Piensan que es lucrativo, y como agradecimiento deben pagarles algo". En otras palabras, la fotografía se interpreta como una trasgresión porque implica la invasión del "otro", mayoritariamente el extranjero occidental que se ha convertido en un observador y consumidor insaciable. Los discursos oscilan entre la falta de respeto cultural, la utilización de la cámara sin consentimiento y las 
sospechas sobre los beneficios ajenos que los extranjeros sacan de sus imágenes. Por eso, empiezan a aparecer discursos en torno a la mercantilización de la cultura y sobre el negocio del consumo turístico. Así, los que viven cotidianamente del turismo, como los niños que piden limosna o se convierten en guías espontáneos, o las mujeres que venden ámbar, collares, bolsos, rebozos y huipiles en los mercados o por los alrededores de la iglesia, los que no tienen tanto beneficio monetario como los mandatarios ni controlan redes comerciales o del transporte, buscan otras estrategias y quieren posar ante las cámaras para ganar algo a cambio y subsistir de una economía informal incrustada ya en el ámbito turístico.

Pero la prohibición permanece, se ha endurecido incluso en los últimos años ante la mayor presencia de turistas en la cabecera, cada día. Las autoridades políticas difunden la pureza y conservación de la cultura tradicional ante ojos extraños, exigen que las mujeres conserven sus trajes tradicionales ante los turistas y establece un código de silencio sobre información comunitaria que consideran privada. Además, el mercado turístico exige la puesta en escena de lo más vistoso y posible de ser mercantilizado como auténtico. Por eso, la reproducción visual debe ser controlada y ahora los mandatarios empiezan a contratar cámaras indígenas para documentar visualmente un mundo acorde con las tradiciones comunales. En los alrededores de la iglesia, o en los mercados de artesanías, se ofrecen postales turísticas que enseñan los aspectos más tradicionales de su cultura (artesanías, fiestas, rituales, vistas generales de la iglesia y el cementerio) que permiten al visitante la oportunidad de llevarse un recuerdo visual de estos lugares, al mismo tiempo que se venden guías turísticas con fotografías y textos de autoría indígena que explican las características particulares del municipio. En otras palabras, con las prohibiciones impuestas por los mandatarios lo que parece ponerse en cuestión no son solo los efectos que el acto de fotografiar tiene ante el cuerpo y el alma, sino el uso que hacen los extranjeros (turistas, visitantes de paso y otras personas externas) de la producción, distribución y consumo de imágenes indígenas. Aquí, cuando los fotógrafos son indígenas o personas que han pagado una cantidad elevada de dinero para poder utilizar la cámara, no pesan las prohibiciones ni aparecen los imaginarios sobre cámaras que roban almas. Está en juego la exhibición de la cultura comercializada como tradicional, caracterizada por su espiritualidad y sus espacios sagrados, sus fiestas y ceremonias en honor a los santos y sus rituales de rezo y curación que incorporan creencias en almas perdidas y enfermas. Aquí, en definitiva, lo que realmente parece estar en juego es el control de la representación que poseen las élites para legitimar poderes y posiciones, controlar recursos y manipular el artefacto de escenificación turística para sus intereses políticos.

\section{La ruta de las artesanías en Zinacantán}

Zinacantán (20) es un municipio más pequeño y no hay tanta población recorriendo la cabecera como sucede en el vecino municipio de Chamula. El centro ceremonial y político cuenta con los servicios de iglesia, escuelas, centros sanitarios, tiendas pequeñas de alimentos y otros enseres, y la Presidencia Municipal que está regida por las élites indígenas. En la cabecera viven únicamente las autoridades y algunas familias que se dedican al negocio de las artesanías, mientras que la gran mayoría de la población campesina vive también en los parajes de alrededor y no frecuentan el centro más que los días de mercado para acudir a la iglesia, en fiestas importantes o para reuniones comunales. El Sistema de Cargos no es tan visible como en Chamula porque las ceremonias suelen ser privadas o se realizan en las cuevas y montañas. Requiere también para los mayordomos ostentar un cargo obligatorio e implica grandes gastos ceremoniales para conseguir el prestigio necesario para subir en la escala social. Sin embargo, a diferencia de San Juan Chamula cuya clase política y religiosa maneja numerosos negocios en la región incluidos los del turismo, en Zinacantán se han desarrollado dos estrategias productivas diferenciadas por género: las mujeres se han especializado en la producción y venta de textiles, mayoritariamente para un consumo turístico, mientras los hombres se dedican al cultivo de flores y han creado organizaciones internas para su recogida y trasporte a otras partes del país, incluida la capital de la república mexicana.

Para poder acceder a la cabecera municipal, todos los visitantes deben pagar una entrada y pueden llegar directamente al centro ceremonial y político o dar una vuelta por los alrededores para observar los invernaderos de flores. La vida ceremonial no se exhibe ni se mercantiliza de la misma forma que en San Juan Chamula. A su llegada a la cabecera, se visita la iglesia principal de San Lorenzo y la Capilla del Señor de Esquipulas, pero estos recintos suelen estar vacíos cuando llegan los turistas, y en caso de alguna celebración se prohíbe la entrada a los visitantes. Las curaciones tampoco se han convertido en atractivo turístico y se realizan en un ámbito oculto al turista. En su lugar, han aparecido tiendas de textiles en el 
interior de algunas casas particulares de tejedoras a las que acuden y son guiados los grupos de turistas. Allí el escenario turístico se construye mediante la exhibición de la producción y venta de textiles, promocionados por los guías como "auténticas artesanías mayas que plasman ideas, leyendas y mitos antiguos", o como "un arte indígena confeccionado por mujeres en el antiguo telar de cintura." La escenificación para el turista incluye considerar que el oficio de tejer es una tradición arraigada en Zinacantán gracias a las mujeres que lo han conservado como su actividad principal. No importa que veas que todavía dependen de un pequeño sustento agrícola de maíz y frijol, del comercio de alimentos a pequeña escala, y que escuches que muchos jóvenes ya están en "el otro lado" y han traspasado la frontera para buscar mejores oportunidades de vida. Lo que importa es exhibir una cultura pintoresca y de tradiciones arraigadas que oculta otros procesos sociales y económicos marginales.

Para las zinacantecas, la producción y venta de textiles se ha convertido en la estrategia principal para el sustento familiar y participan tejedoras de diferentes edades y generaciones para elevar la producción y para que el negocio sea más rentable. Con la explosión turística se ha incrementado la actividad comercial y cada día se abren más tiendas con toda clase de textiles. Los turistas son conducidos a estas casa/tiendas de las artesanas donde todo está perfectamente adecuado al imaginario turístico: altares doméstico con velas, imágenes de santos y otros ornamentos sagrados, observación de la confección de piezas textiles por mujeres indígenas que utilizan el antiguo telar de cintura, visita a la cocina con un almuerzo incluido de tortillas con diferentes salsas, muestra de todos los textiles a la venta y algunos otros exhibidos como museo de la indumentaria regional, y degustación de la bebida sagrada posh que, dicho sea de paso, también está a la venta para quien quiera adquirir el licor como recuerdo. En estos recintos se permite abiertamente la utilización de las cámaras y las familias que abren sus puertas a los visitantes posan ante ellos como parte de la oferta turística. Los guías "animan" al turista a que tome fotografías y rememore su visita mientras incitan a un intercambio económico para validar esta permisividad: "Vamos a visitar una familia local donde ustedes pueden tomar fotografías, vamos a probar un taco, alimento básico, luego beberemos un poco de posh y si ustedes tiene interés de comprar algún recuerdo, algún regalo, pueden hacerlo con la familia". Se permite incluso posar ante las cámaras con el atuendo característico de las bodas zinacantecas y los turistas se disfrazan para convertirse por un momento en auténticos indígenas que acuden a la ceremonia. Los visitantes aprovechan esta permisividad fotográfica para tomar instantáneas de mujeres que visten con lujosos trajes y de estancias, como la cocina y el altar doméstico, y tienen la oportunidad de adquirir todo tipo de souvenirs y experiencias.

Los turistas autentifican su experiencia mediante la visita a un mundo de tradiciones artesanales que incluye el ritual de reproducir visualmente su experiencia. Para estos visitantes la utilización de una cámara significa rememorar sus experiencias, mientras los guías legitiman su posición por haber conseguido esta permisividad. Cada uno adopta el rol esperado: turistas ansiosos por recodar lo que ven y luego poder enseñar orgullosos el contacto realizado con lo exótico; guías que demuestran su destreza en el negocio, conceden privilegios a los invitados y ya no requieren apelar a discursos sobre cuerpos ni almas. Además, esta permisividad de utilizar cámaras se ha extendido a otras partes de la cabecera, y ante la iglesia principal siempre hay mujeres y niños que posan por dinero ante las cámaras de los turistas. Permanece no obstante la prohibición de fotografiar los espacios sagrados, comunitarios y otros privados, a los que no se accede fácilmente, y son preservados y ocultados de la atenta mirada del invasor extranjero. Los guías son los que explican los lugares adecuados y las reglas existentes para poder tomar la foto e, incluso, se ofrecen como cámaras espontáneos:

"Algunos niños se les van a acercar, les van a decir, 'foto, foto', quiere decir si se quieren tomar una foto con ellos. ¿Por qué?, porque están vestidos con el traje tradicional de Zinacantán que como pueden ver es muy bonito. Después de la foto les van a cobrar 10 pesos. A las supermodelos les pagan millones de dólares por una foto y creo que 10 pesos no es tanto, sobretodo si queremos la foto. Si no la queremos, les decimos 'no gracias' de la manera más amable que podamos. Por favor, las veces que nos sea necesario y listo (...). Miren chicos, ellos son los niños, la gente que se dedican a lo de las fotos. Normalmente es muy fácil, pero ahorita ya hay muchos grupos, y ya se volvió una mafia donde todos quieren que sea nada más con ellos. Por supuesto lo de la foto no es obligación. Es para todo el grupo, no es por niños, es para toda el grupo. Por supuesto que dinero es dinero verdad?, más mejor. Si les dan dos millones de pesos pues van a ser los niños más felices del mundo (...). Y si lo quieren hacer, por supuesto porque no es obligación, me pueden dar su cámara y yo les tomo la foto".

En estas fotografías turísticas de espacios públicos, los indígenas posan de acuerdo a pautas occidentales, 
de frente y mirando fijamente a la cámara, como si repitieran los gustos externos y utilizaran los imaginarios turísticos para reproducirse a sí mismos. Aquí el valor de una fotografía se equipara a su valor económico, y se saben actores que posan ante un escenario cargado de estereotipos con trajes y entorno adecuado. Mientras en los escenarios públicos se atreven a observar el objetivo, en los privados, mujeres y otros participantes aparecen ajenos a la cámara y nunca miran de frente. Aquí las actuaciones se condensan y los atuendos, el espacio adornado, las actividades y los objetos tradicionales que rodean a los actores se convierten en los símbolos que testifican su autenticidad. Aquí saben que su actuación en el escenario adecuado, como cuando trabajan en sus telares o cuando cocinan las tortillas en el comal, es lo que concede valor a la fotografía. Su valor económico se vislumbra en ofrecerse a sí mismos como un fragmento de lo que exponen la venta, reflejando una tradición en unos trajes, como huipiles, faldas y rebozos que también aparecen colgados en las paredes. Y así transforman su cuerpo en una exhibición y presentación del papel social asignado, como afirma Goffman (1981), para posar ante las cámaras y convertirse en una imagen mercantilizada sobre su tradición cultural.

Se trata de una estrategia de venta que requiere incorporarse a los imaginarios turísticos y valerse de la permisividad fotográfica para mantenerse en el negocio. El turismo ha contribuido a que estos pequeños negocios prosperen y se han ido innovando espacios de exhibición que son cada vez más sofisticados: mujeres vestidas con atuendos brillantes y cuidados peinados, cocinas decoradas con ornamentos antiguos y con mazorcas de maíz de diferentes colores y prendas a la venta que han incorporado nuevos diseños y colores para acomodarse a gustos externos. Las zinacantecas son ahora expertas vendedoras de la mercancía que exhiben, enseñan múltiples prendas y regatean hasta sacar algún beneficio, parte del cual va a parar a manos de los guías turísticos con pactos monetarios beneficiosos para ambas partes. Desde luego, lo que está en juego es la mercantilización de la cultura indígena en ámbitos adecuados para su escenificación, y se ocultan prácticas y objetos (como cocinas a gas, refrigeradores, televisores, radios y otros aparatos eléctricos) para no demostrar abiertamente su incorporación al mundo capitalista. Se trata, en definitiva, de un escenario frontal que esconde un mundo trasero marginal que sobrevive de los ingresos que comporta el turismo. Un mundo frontal que esconde una dinámica competitiva de tejedoras que confeccionan prendas unas tras otras y rellenan lo que falta con piezas adquiridas a otras tejedoras de otros municipios y de otros países centroamericanos como Guatemala. Un mundo de textiles que se transforma para la demanda externa, y de mujeres que requieren escenificar un mundo artesano para exhibir la autenticidad buscada y anhelada por el turista.

\section{Conclusiones: cámaras y prohibiciones}

En el mercado de la autenticidad étnica de Los Altos se exhibe un mundo pintoresco de cultura exótica y tradiciones indígenas; una cultura hecha a base de fragmentos de trajes tradicionales, artesanías, festividades y rituales. Estos son los espacios frontales puestos en escena para un turista interesado en encontrar una autenticidad original y que busca signos, señales reconocibles para verificar sus imaginarios. En los escenarios frontales, el turista ya no encuentra solo un espacio que sirve para observar, sino que quiere recorrerlo, participar y sentirse parte del mismo. Allí verifica sus estereotipos sobre el "otro", y lo imagina y sueña con la esperanza de encontrar una variedad en un mundo cada vez más uniformado. Alli recolecta trozos de esos otros, intenta hacer fotografías, adquiere y compra objetos como un culto al pasado, y lo inmutable pasa a convertirse en testimonio de su viaje. Pero ese "otro" que ahora se sueña lejos del mundo cotidiano no se halla estancado en ese tiempo irreal que las agencias de viajes prometen, sino en un espacio turístico presente donde escenifica los estereotipos turísticos. Allí, selecciona espacios frontales por ser los más representativos y más rentables, los cuales esconden también un mundo trasero de luchas internas, poderes y competencias. Por eso, los escenarios frontales sirven para los anfitriones para conseguir recursos, pero también se han convertido en lugares de presentación, negociación y conflicto: permiten trabajar y sobrevivir a muchas personas y a otras reclamar protagonismo y desplazar estos beneficios al ámbito social. Se han convertido en realidad en espacios híbridos, creados por y para el turismo, donde turistas y locales, invitados y anfitriones, se convierten en una matriz común de interacción y donde se exhibe la "otredad" como presentación social para reclamar, rescatar o reinventar una cultura particular (Cohen 1988, MacCanell 2003, Santana 1997).

En Los Altos, el empoderamiento de algunos sectores indígenas se vislumbra ahora en estos escenarios de presentación turística donde, además, se cuestiona, prohíbe o se limitan algunos comportamientos y 
acciones de los turistas. Se han comparado dos municipios indígenas para indagar en este empoderamiento y para analizar cómo, en cada espacio de presentación, no solo entra en juego una escenificación presentada como auténtica, sino un proceso contextual y relacional con amplias repercusiones, interpretaciones y acciones diversas entre los locales. Así, mientras los indígenas se reapropian y utilizan el discurso esencialista turístico para posicionarse ante los invitados, a la vez demarcan sus fronteras imponiendo nuevas reglas de interacción: en Zinacantán exhibiendo una mercancía étnica y permitiendo la utilización de las cámaras para fines comerciales, y en San Juan Chamula enseñando ámbitos sagrados bajo el poder de unas élites que acentúan las prohibiciones. $Y$ es que en esta permisividad o prohibición de la reproducción visual entra en juego cómo te presentas, cómo mercantilizas tu cultura y cómo interpretas a ese "otro" ahora turista. En ambos casos se enseñan solo fragmentos de una cultura rescatada o reinventada que se adorna con símbolos étnicos. En ambos casos se mercantilizan escenas, objetos y personas y se utiliza una hospitalidad comercializada (Cohen 1988) para que funcione el intercambio comercial. Pero no se juegan los mismos roles ni se dan las mismas oportunidades o beneficios para los locales; las tejedoras buscan beneficios económicos individuales y se han incorporado a un mercado competitivo capitalista, al contrario de los mandatarios chamulas que han convertido el turismo en un ámbito político para controlar recursos y manipular el artefacto de representación adornado como bienes culturales.

Por eso, los ámbitos de presentación en ambos municipios son tan diferentes y la interacción con los turistas varía de un espacio a otro. En el caso específico de Zinacantán se ha construido un espacio delantero claramente identificable: una casa de tejedoras especialmente preparada para la visita turística, adornada con símbolos tradicionales, que se separa claramente de los espacios privados y familiares ocultos al visitante. En esos espacios ocultos los anfitriones se desenvuelven como cualquier otro grupo social, pero requieren reconstruir un mundo indígena frontal con cierto control sobre lo representado. Es en este espacio frontal donde se escenifica la vida cotidiana de mujeres que realizan tareas asociadas a su género, como cocinar o tejer la ropa, pero en un entorno cuidado y vistoso para que les permita vivir y sobrevivir del mismo. Se trata de una simulación en la que entra en juego la presentación de signos y discursos claramente identificables como objeto turístico y que sean reconocidos por los imaginarios que circulan a nivel global. Se exponen artesanas y artesanías en un museo de variedades y de objetos valiosos para ser resignificados; sus oficios son arte étnico y tradición indígena; sus objetos son símbolos estereotipados de la representación de lo exótico e inmutable (Cohen 1988, MacCannell 2003, Santana 1997). Aquí la interacción es permitida para el intercambio económico y como tal, se permite su reproducción visual. Pero todo está planificado para sacar mayores beneficios: se exploran los gustos de los turistas, los objetos más demandados y los visitantes que hacen mayores inversiones. El turismo ha permitido que los tejidos que efectuaban las mujeres para uso propio tengan ahora significados globales y se conviertan en una mercancía demandada y buscada. El turismo, por tanto, se interpreta como dinero y como una vía para conseguir unos bienes necesarios para continuar su propia reproducción social.

En Chamula, al contrario, el espacio frontal parece ser un auténtico escenario trasero. Los turistas observan en primera fila los rituales indígenas y aparecen como intrusos ante la vida sagrada de los indígenas. No hay interacción como el caso anterior en la casa de las tejedoras, ni tampoco posibilidad de llevarse un recuerdo visual de la visita. Sin embargo, se trata de un espacio frontal construido como un escenario teatralizado que requiere que los indígenas se conviertan en actores inmunes al palco que los observa y que pacten con antelación esa indiferencia. Nadie parece percatarse que en este mismo espacio hay otros curanderos que ofrecen sus servicios a los turistas por un precio módico, o que los anfitriones digan que prefieren acudir a la iglesia por las tardes para realizar sus ceremonias y no ser molestados por los tours matutinos de los turistas. Además, existen otros rituales que no permiten las visitas turísticas, como los que se realizan en cuevas o en ríos cuando los mayordomos lavan la ropa de los santos, cuando los mayordomos pasean a los santos, o cuando se celebran fiestas señaladas que los anfitriones suelen evitar que los turistas las observen. Pero en el caso de Chamula, la iglesia no es solo un espacio de presentación sino de control y exhibición de poderes. Allí los creyentes van a curarse y a orar, pero también hay una exhibición de los cargos religiosos y de posicionales sociales. La iglesia es un pequeño mundo Chamula que reproduce el orden social y proporciona el escenario adecuado para que los indígenas comulguen con la adscripción comunitaria y legitimen la jerarquía política y religiosa existente (Douglas 1973). Por eso, la oferta turística de San Juan Chamula no puede ser pensada únicamente como un producto mercantilizado sin tener cuenta el papel que ocupan las élites. Son estas élites las que han seleccionado una ruta de lo sagrado como una estrategia considerada como adecuada para su presentación social y las que han convertido la iglesia, como otros espacios frontales, en el lugar idóneo para exhibir y negociar su identidad 
tanto hacia fuera como hacia dentro. Son grupos en el poder que imponen reglas e interpretan ahora a las cámaras como objetos externos, contaminantes y peligrosos para mantener sus tradiciones. Las cámaras, en el fondo, son un símbolo de los propios turistas y de una práctica consumista que puede llegar a devorar y aniquilar la forma de vida local (Greenwood 1992).

El turismo tiene repercusiones en muchos ámbitos locales y esta polaridad entre anfitriones e invitados se interpreta y es utilizada de múltiples formas. El turismo es, en realidad, una relación económica y de transacción en el que los primeros se presentan ante los segundos para ser consumidos y sacar algún beneficio. La presentación local depende de discursos e imaginarios ajenos que han sido construidos desde fuera por una industria turística que exhibe su singularidad y exotismo al mismo tiempo que esconde la auténtica realidad marginal en la que vive la gran mayoría. Y mientras los anfitriones se presentan para parecer auténticos, corren imaginarios locales sobre los turistas como intrusos y forasteros, y como ávidos consumistas que intentan comprar y reproducir cualquier faceta de sus vidas. En su caso, las cámaras y sus imágenes se convierten en los símbolos de esa intromisión, son valiosos objetos para ser significados, valorados y negociados, y se transforman en máquinas para hacer dinero o se vuelven objetos malignos que enferman, devoran o contaminan todo lo que tocan, copian o reproducen.

\section{Notas}

1. El estado de Chiapas ha sido promovido por cadenas de televisión, como TV Azteca y Televisa, que respectivamente han producido dos telenovelas ambientadas en el estado y estrenadas ambas en el año 2009: Mi pecado, de la cadena Televisa, ambientada en la ciudad de San Cristóbal de las Casas y Pasión morena estrenada por TV Azteca y ambientada en la Selva Lacandona.

2. El estudio forma parte del proyecto de investigación titulado Consumo e imaginarios culturales con investigadores de la Universidad de Valencia en convenio con el Centro de Estudios Superiores de México y Centroamérica (CESMECA) de la Universidad de Ciencias y Artes de Chiapas (UNICACH). El trabajo de campo se ha llevado a cabo en julio y agosto de 2012 y julio y agosto de 2014 en la ciudad de San Cristóbal de las Casas y las comunidades indígenas con mayor afluencia turSe enfoca ñhuamula y Zinacantles imaginarios urbacci, nsumo cultural en los Altos de Chiapas docuemntar visualemnte los acontenística, especialmente en San Juan Chamula y Zinacantán.

3. El estado de Chiapas cuenta con 121 municipios que se agrupan en quince regiones socioeconómicas. La región Altos Tzotzil-Tzeltal está formada por 17 municipios y en el año 2010 la población total se elevaba a 601,190 habitantes, representando el $12,5 \%$ a nivel estatal. Se caracteriza por ser una de las regiones con mayor porcentaje de hablantes de lengua indígena de 3 o más años $(75,2 \%)$, solo superado por la región Tulijá Tzeltal-Chol en el norte del estado de Chiapas (89,7\%). Su población indígena se concentra en 15 de los 17 municipios y mayoritariamente habla la lengua tzotzil $(62,3 \%)$ y tzeltal $(37,2 \%)$ (INEGI 2010, CEIEG).

4. Según el Consejo Nacional de Población (CONAPO), en el año 2010 la región tenía un nivel de marginación Muy Alto. Los datos de INEGI en el año 2010 revelan que 56,7\% de la población activa trabaja en la agricultura y $69,4 \%$ tiene un salario igual o inferior al salario mínimo de 65 pesos por día. A nivel educativo, el $24,5 \%$ de la población de 12 o más años es analfabeta y el $66,4 \%$ de 3 o más años solo tiene el nivel de escolaridad Primaria. Por último, un 58,8\% vive en localidades con menos de 2.500 habitantes, el $24,2 \%$ no posee agua entubada y el 3,9\% no tiene energía eléctrica en sus viviendas. (CONAPO 2010, INEGI 2000).

http://www.conapo.gob.mx

5. Desde la década de 1970s, se producen conflictos político-religiosos en algunos municipios indígenas, principalmente en Chamula, pero también en Chalchiuitán, Chenalhó, Mitontic, Chanal, Pantelhó, Zinacantán, Amatenango del Valle, Oxchuc o Venustiano Carranza. Entre las religiones que profesan se encuentran Iglesia Nacional Presbiteriana, Bautista, Iglesia de Dios, Pentecostés, Iglesia Evangélica, Adventistas del Séptimo Día, Testigos de Jehová, Sabático, Asamblea de Dios y Cristiana y de reciente aparición la religión musulmana (Cantón Delgado 1997, Melel Xojobal 2000, Morquecho 1992, Robledo Hernández 
6. El proyecto turístico del "Mundo Maya" empezó a desarrollarse en 1989 por la Secretaria de Turismo de México (SECTUR) junto a los países vecinos de Belice, EI Salvador, Guatemala y Honduras. Se basa en un acuerdo internacional para coordinar y fortalecer acciones de promoción y comercialización de la "ruta maya" y facilitar las inversiones extranjeras y nacionales.

http://www.sectur.gob.mx/es/sectur/sect_Programa_Mundo_Maya

7. La ciudad se declara Zona de Monumentos Históricos en el año 1986 por el Instituto Nacional de Antropología e Historia (INAH) y posteriormente, en el año 2003, es catalogada como Pueblo Mágico por la Secretaria de Turismo.

8. Dean MacCannell (2003) retoma los conceptos de Erving Goffman de front y back para elaborar su teoría del escenario turístico. En la región frontal se desarrolla un entorno escenificado de recorridos y tours turísticos y lugares de servicios y ocio como restaurantes, hoteles y tiendas. Pero la zona trasera es el espacio de las formas de vida locales y ocultas al turista. En muchos casos, son lugares marcados por la marginación y pobreza, que no han sido escenificados ni alterados para la mirada del turista y que ejemplifican la realidad vivida por los que se convierten en anfitriones.

9. Gayatri Chakravorty Spivak (1988) ha utilizado el concepto de esencialismo estratégico para explicar el uso de los discursos dominantes por parte de los subalternos, los grupos sociales olvidados (campesinos, obreros, mujeres, tribus y otros grupos fuera de la modernidad) para que logren una representatividad política y cultural dentro de la sociedad dominante.

10. Las citas pertenecen a diferentes guías turísticos que efectúan diariamente tours hacia los dos municipios indígenas.

11. San Juan Chamula es el municipio indígena más poblado de toda la región, y el año 2010 tenía una población total de 76.941 habitantes, con una mayoría de población de 3 o más años que habla la lengua tzotzil (99,9\%) (INEGI 2010). En el año 2005, en la cabecera vivían 2.959 habitantes mientras el resto de la población se dispersa en las 126 localidades o parajes (INEGI 2005 y 2010).

12. En San Juan Chamula, los trabajadores agropecuarios representan el $63,4 \%$, seguida del $22 \%$ en la industria y un $9,4 \%$ en el comercio, aunque se da el caso de personas que combinan varias ocupaciones para enfrentar la subsistencia familiar (INEGI 2000).

13. La nueva élite indígena tomó el poder en la década de 1950 apoyada por la política indigenista y por el Partido Revolucionario Institucional (PRI) y sustituyó el poder centralizado de los cabildos indígenas que servían de intermediarios entre el poder mestizo centralizado en San Cristóbal y el pueblo indígena. En 1951 el estado mexicano promovió la creación del Instituto Nacional Indigenista (INI) y fundó el primer centro coordinador tzeltal-tzotzil en la región Altos con la intención de integrar a los indígenas en el estado mexicano. La política indigenista formó profesores bilingües y promotores del desarrollo y la salud que se incorporaron a las filas de la burocracia. Con el tiempo, estos indígenas llegaron a formar parte de la estructura de poder en Los Altos, ascendieron en los ámbitos políticos y económicos en sus comunidades e impusieron sus intereses personales (Pineda 1995, Rus 1995 y 2011, Viqueira 1995, 1999 y 2002).

14. El Sistema de Cargos aparece en el s. XIX como una práctica religiosa heredada de la época colonial y como consecuencia de la legitimación de las estructuras de poder caciquiles indígenas que se independizan de las cofradías religiosas ladinas (Viqueira 2002).

15. Para profundizar en el discurso tradicionalista que las élites utilizan ante los turistas es interesante el análisis de la Guía San Juan Chamula. Chiapas. Historia de un Pueblo y sus Tradiciones, que se vende en la cabecera como propaganda turística y ha sido redactada bajo la supervisión de los representantes políticos del municipio. Este documento ilustra el discurso esencialista que utiliza la clase política para presentar al indígena de Chamula caracterizado mayoritariamente por su particular cosmovisión ritual y ceremonial.

16. En Los Altos existen diferentes tipos de especialistas médicos que cuentan con el reconocimiento de la comunidad: pulsadores, rezadores de cerros, hierberos, parteras y hueseros. El pulsador (I'lol), es el que 
posee mayor prestigio, se considera que tiene un gran conocimiento y puede curar a los enfermos a través del pulso y la interpretación de los sueños; el rezador de los cerros (K'oponej witz) se encarga de proteger a la comunidad de males y desastres naturales; el hierbero (Ac'vomol) utiliza la herbolaria como método terapéutico. La partera (Jvet'ome) atiende los embarazos y los partos y soba, acomoda y levanta al niño; y finalmente el huesero (Tzac'bak) que trata la enfermedad de los huesos como las fracturas (información conseguida en el Museo de Medicina Maya de San Cristóbal).

17. Licor de caña de azúcar. Antiguamente tenía una utilidad básicamente ritual en fiestas y en curaciones, pero en la actualidad se vende hasta en comercios en la ciudad. Los mayores productores de esta bebida alcohólica se encuentran en el municipio de Chamula, quienes a su vez venden el producto en los parajes del municipio y al resto de comunidades de la región de Los Altos.

18. Por ejemplo, para la enfermedad del Mucta Chulelal (enfermedad del alma grande) es necesario comprar: una vela blanca (para dios que está en el cielo), dos velas de oro (para envidia y mal echado), dos velas amarillas (para envidia y mal echado), y dos velas rojas (para envidia y mal echado). Para curar y prevenir enfermedades: 13 velas chicas de color blanco, 13 chicas de color oro, 13 chicas de color amarillo y 13 chicas de color rojo; y para curar el espanto: dos velas chicas de color blanco y una vela chica de color oro. La presencia de velas negras ante el enfermo o sus familiares, implica que se trata de una enfermedad incurable y cercana a la muerte (información conseguida en el Museo de Medicina Maya de San Cristóbal).

19. Las citas que aparecen en el texto son confidenciales y pertenecen a informantes que fueron entrevistados durante el trabajo de campo realizado en 2012.

20. En el año 2010 El municipio de Zinacantán tenía una población total de 36.489 habitantes y al igual que San Juan Chamula, con una mayoría de población de 3 o más años que habla la lengua tzotzil (99,9\%) (INEGI 2010). El 64\% de la población ocupada se dedica a la agricultura, seguida del $17,3 \%$ a la industria y el $12.6 \%$ al comercio. En el año 2005, en la cabecera vivían 3.686 habitantes mientras el resto de la población se dispersaba en 44 parajes rurales (INEGI 2005 y 2010).

\section{Bibliografía}

Bank, Marcus (y Howard Morphy)

1997 "Introduction: rethinking visual anthropology", en Marcus Banks y Howard Morphy (eds.), Rethinking Visual Anthropology. London, Yale University Press and New Haven and London:1-35.

Boissevain, Jeremy

2005 "Rituales ocultos. Protegiendo la cultura de la mirada turística", Pasos. Revista de turismo y Patrimonio Cultural (La Laguna), vol. 3, nº 2: 217-228.

Bourdieu, Pierre

1993 La fotografía un arte intermedio. México, Nueva Imagen.

Cantón Delgado, Manuela

1997 "Las expulsiones indígenas en Los Altos de Chiapas: algo más que un problema de cambio religioso", Mesoamérica (South Woodstock, Vermont, Estados Unidos y La Antigua, Guatemala), n 33: 147-169.

CEIEG. Comité Estatal de Información Estadística y Geográfica de Chiapas

www.ceieg.chiapas.gob.mx

CONAPO. Consejo Nacional de Población

2010 Índice de marginación por entidad federativa y municipio 2010.

http://www.conapo.gob.mx

Cohen, Erik 
1988 "Authenticity and commoditization in tourism", Annals of Tourism Research (USA), vol. 15: 371-386.

Douglas, Mary

1973 Pureza y peligro. Un análisis de los conceptos de contaminación y tabú. Madrid, Siglo XXI.

Edwards, Elisabeth

1992 "Introductory Essays. Historical and theoretical perspectives", en Elisabeth Edwards (ed.), Anthropology and photography 1860-1920. London, Yale University Press and New Haven and London: 317.

Freyermuth, Graciela

1993 Médicos tradicionales y médicos alópatas. Un encuentro difícil en Los Altos de Chiapas. México, Gobierno del estado de Chiapas, Instituto Chiapaneco de Cultura y Centro de Investigaciones y Estudios Superiores en Antropología Social.

Goffman, Erving

1981 La presentación de la persona en la vida cotidiana. Buenos Aires, Amorrortu.

Greenwood, Davydd J.

1992 "La cultura al peso: perspectiva antropológica del turismo en tanto proceso de mercantilización cultural", en Valene Smith (comp.), Anfitriones e Invitados. Antropología del Turismo. Madrid, Endymion: 257-279.

Guiteras, Calixta

1965 Los peligros del alma. Visión del mundo de un tzotzil. México, FCE, 1996.

INEGI. Instituto Nacional de Estadística, Geografía e Informática

2000 XII Censo general de población y vivienda.

2005 Conteo de población y vivienda.

2010 Censo de población y vivienda.

http://www.inegi.org.mx/

MacCannell, Dean

2003 El turista, una nueva teoría de la clase ociosa. Barcelona, Melusina.

Melel Xojobal

2000 Rumbo a la calle... El trabajo infantil una estrategia de sobrevivencia. San Cristóbal de Las Casas, Fray Bartolomé de las Casas.

Morquecho, Gaspar

1992 Los indios en proceso de organización. La organización indígena de Los Altos de Chiapas, Criach. San Cristóbal de Las Casas, Universidad Autónoma de Chiapas.

Pineda, Olivia

1995 "Maestros Bilingües, burocracia y poder político en Los Altos de Chiapas", en Juan Pedro Viqueira y Mario Humberto Ruz (eds.), Chiapas. Los rumbos de otra historia. México, UNAM-CIESAS-CEMCAUniversidad de Guadalajara: 279-300.

Pitarch, Pedro

1996 Ch'ulel: una etnografía de las almas tzeltales. México, FCE.

Pratt, Mary Louise

1992 Ojos imperiales. Literatura de viajes y transculturación. México, FCE, 2010.

Robledo Hernández, Gabriela Patricia

1997 Disidencia y religión. Los expulsados de San Juan Chamula. Tuxtla Gutiérrez, UACH.

Rus, Jan

1995 "La comunidad revolucionaria institucional: la subversión del gobierno indígena en Los Altos de 
Chiapas 1936-1968", en Juan Pedro Viqueira y Mario Humberto Ruz (eds.), Chiapas. Los rumbos de otra historia. México, UNAM-CIESAS-CEMCA-Universidad de Guadalajara: 251-277.

2011 El ocaso de las fincas y la transformación de la sociedad indígena de Los Altos de Chiapas, 19742009. México, UNICACH/CESMECA.

Sánchez Flores, Magdalena Patricia

1995 "De la ciudad real a la ciudad escaparate", en Diana Guillén (coord.), Chiapas una modernidad inconclusa. México, Instituto Mora: 72-113.

Santana, Agustín,

1997 Antropología del turismo. ¿Nuevas hordas, viejas culturas?. Barcelona, Ariel.

2003a "Turismo cultural, culturas turísticas", Horizontes Antropológicos (Porto Alegre), n 20: 31-57.

2003b "Patrimonios culturales y turistas: Unos leen lo que otros miran", Pasos. Revista de turismo y

Patrimonio Cultural (La Laguna), vol. 1, nº 1: 1-12.

Scheper-Hughes, Nancy

1997 La muerte sin Ilanto. Violencia y vida cotidiana en Brasil. Barcelona, Ariel.

SECTUR. Secretaria de Turismo

www.inah.gob.mx;

www.sectur.gob.mx/es/sectur/sect Pueblos Magicos,

Smith, Valene S.

1992 "Introducción”, en Valene Smith (comp.), Anfitriones e Invitados. Antropología del Turismo. Madrid, Endymion: 15-41.

Sontag, Susan

1981 Sobre la fotografía. Barcelona, Edhasa.

Spivak, Gayatri Chakravorty

1988 "Subaltern Studies. Deconstructing Historiography”, en R. Guha y G. Spivak (eds.), Selected Subaltern

Studies. New York, Oxford University Press: 3-34.

Urry, John

1990 The Tourist Gaze. London, Sage, 2003.

Urry, John (y Carol Crawshaw)

1995 "Turismo e consumo visual", Revista Critica de Ciència Sociais (Coimbra), nº 43: 47-68.

Van den Berghe, Pierre L.

1994 The Quest of the other. Ethnic Tourism in San Cristóbal de Las Casas, México. London, University of Washington Press.

1995 "Marketing mayas. Ethnic Tourism Promotion in Mexico", Annals of Tourism Research, vol. 22, n 3: 568-588.

Viqueira, Juan Pedro

1995 "Los Altos de Chiapas: una introducción general", en Juan Pedro Viqueira y Mario Humberto Ruz (eds.), Chiapas. Los rumbos de otra historia. México D.F., UNAM-CIESAS-CEMCA-Universidad de Guadalajara: 219-236.

1999 “Los peligros del Chiapas imaginario”, Letras Libres (México), nº 1: 22-28 y 96-97.

2002 Encrucijadas chiapanecas. Economía, religión e identidades. México, Tusquets.

WANG, Ning

1999 "Rethinking Authenticity in Tourism Experience", Annals of Tourism Research, vol. 26, n 2: 349-70. 
